\title{
Prevalence of Depression among Arab Women with Type 2 Diabetes: A Systematic Review and Meta-Analysis
}

\author{
Sana Hawamdeh ${ }^{1 *}$, Wireen Leila T. Dator ${ }^{1}$, Hamzeh Y. Abunab ${ }^{2}$ \\ ${ }^{1}$ College of Nursing, Princess Nourah Bint Abdulrahman University, Riyadh, KSA \\ ${ }^{2}$ Schoolof Nursing, Saint Louis University, Baguio City, Philippines \\ Email: "hawamdehs@gmail.com
}

Received 22 December 2015; accepted 14 May 2016; published 17 May 2016

Copyright (C) 2016 by authors and Scientific Research Publishing Inc.

This work is licensed under the Creative Commons Attribution International License (CC BY). http://creativecommons.org/licenses/by/4.0/

(c) (i) Open Access

\begin{abstract}
Objective: To systematically review and meta-analyze the literature estimating the cross-sectional prevalence of depression in Arab women with Type 2 diabetes in Arab countries. Design: Systematic review and meta-analysis of quantitative studies. Data Sources: The data were collected from scientific databases which included CINAHL, PubMed, Medic, ISI Web of Science, Cochrane library and ERIC published from January 2000 to May 2015. Sources used in all of the included studies were also reviewed. Results: Nine studies were included in the analysis. The criteria included studies that reported on Type 2 diabetes and depression co-morbidity in adult women from the following countries: Iraq, Jordan, Palestine, Qatar, Morocco, Saudi Arabia, Kuwait, United Arab Emirates, Oman, and Yemen. Conclusions: Prevalence rate of depression as comorbidity of Type 2 Diabetes Mellitus among Arab Women in the Arab countries is significant. Despite dearth of studies focusing on the association between depression and diabetes mellitus among Arab women, the prevalence rate revealed from the review merits attention for more gender specific exploratory studies on prevalence and management of these diseases.
\end{abstract}

\section{Keywords}

Diabetes Mellitus, Depression, Women, Arab Countries

\section{Introduction}

Throughout the world, studies have been executed to assess the comorbidity of depression and diabetes [1]. The relationship between Type 2 Diabetes Mellitus (T2DM) and depression has been investigated by numerous re-

"Corresponding author.

How to cite this paper: Hawamdeh, S., Dator, W.L.T. and Abunab, H.Y. (2016) Prevalence of Depression among Arab Women with Type 2 Diabetes: A Systematic Review and Meta-Analysis. Health, 8, 650-657.

http://dx.doi.org/10.4236/health.2016.87068 
searchers. Multiple studies have shown a relationship between T2DM and depression [2]-[4]. A meta-analysis study [5] concluded that depression is associated with a 60\% increased risk of developing T2DM, and T2DM is associated with a modest increased risk of depression.

Worldwide, diabetes is a serious growing concern, as is depression. The World Health Organization has identified the Eastern Mediterranean (EMRO) countries as having one of highest prevalences of T2DM in the world [6]. In the EMRO region, the T2DM prevalence rate for all adults was 14.5\%; however there are variations in distribution of the disease between and within countries. Gender appears to be a factor affecting variation in some countries. For example, in Bahrain women had higher rates of T2DM than men (24.4\% for men and 35.9\% for women); in Kuwait, the rates were almost equal (14.7\% for men and 14.8\% for women); and in Saudi Arabia, the T2DM rates were higher in men than in women (26.2\% for men and $21.5 \%$ for women).

The prevalence of T2DM is expected to increase dramatically over the next 15 years in urban populations of developing countries [7]. More specifically, according to the International Diabetes Federation (IDF), the Gulf Region accounts for 5 of the top 10 countries with the highest prevalence rates of T2DM in the world [8]. This dramatic increase of T2DM prevalence over the last three decades in the Arab countries is very much parallel to the increase of industrial development due to the wealth generated by oil-rich resources in the Arabian Gulf [9]. While the trends of obesity, low glycemic control, and many other factors continue to grow, one can only predict that the future of diabetes is expected to vastly escalate in the Gulf area.

Depression is also prevalent worldwide, with more than 350 million people estimated to be inflicted with the condition [10]. It has been projected that in the year 2020, depression will be the second leading cause of death in the world [11]. The World Health Organization (WHO) concluded that the comorbidity of depression with a chronic illness incrementally deteriorates health outcomes as compared to having depression alone, or any chronic illness alone, or a multiple of chronic illness without the presence of depression [12].

While people with diabetes have been found to have doubled the risk for comorbid depression [13], no causal relationship has been established. As the relationships are still unclear they are described as bidirectional, where T2DM is a risk factor for depression and likewise depression is a risk factor for T2DM. It has been found that T2DM is associated with an increased risk of depression and anxiety disorders [14]. A 2013 study has found that T2DM was significantly more frequent in diabetic women than in control women [3] [15]. This higher prevalence of depression among females has been recorded by numerous studies [16]-[18]. The American Psychiatric Association found that the prevalence rate of depression in females was double the rate in males. The American Diabetes Association has concluded that women experience depression twice as frequent as men, and that depression increases in women with diabetes.

Perhaps the most under-researched demographic throughout most of the health literature is that of Arab women. Dearth of literature focusing on the health of Arab women has been found. The bifurcation of social life among men and women in the Arab countries imposed limited access to research community and restricted exploration mainly to the world of women [19]. This project sought to understand the current literature on comorbidities between depression and T2DM among Arab women in Arab countries. The prevalence of comorbid depression has been consistently significantly higher in diabetic women than in diabetic men [3].

\section{Methodology}

\subsection{Review Questions}

This study aimed to systematically review and meta-analyze the current comorbidity of diabetes and depression in Arab women living in Arab countries. The question for review was framed at the beginning of the project, and the study selection criteria were identified. Reasons for inclusion and exclusion of studies were articulated and recorded. The researchers decided to focus on the comorbidity of diabetes and depression in women living in Arab countries. One of the researchers is currently working with patients in an Arab country. During the course of the researcher's contact with patients, she observed a high proportion of female diabetic patients in health centers, who also suffered from depression. The Arab countries included were listed (Saudi Arabia, UAE, Bahrain, Palestine, Iraq, Jordan, Kuwait, Jordan, Oman, Qatar, Morocco, Syria, and Yemen). These countries were chosen as the women in these countries share many cultural and lifestyle similarities.

\subsection{Literature Search}

The selection criteria was applied in the screening of all the literature found. This was done by defining the 
terms, completing the searches individually, and then reading all of the abstracts. The full articles were then retrieved and selected those articles that fit the selection criteria. The following bibliographic databases were searched, using the EBSCO Academic Complete interface: Academic Search Complete, MedLine Complete, and CINHAL plus with full text. After the initial search, the research team repeated the search using Web of Science. No additional articles were found.

\subsection{Data Extraction}

Data extraction forms were developed, based on those produced by the Cochrane Collaboration [20]. A file of completed data extraction forms for each article included was produced.

\subsection{Quality of the Data}

Included study designs were cohort and cross-sectional studies. The researcher looked for completeness and quality of the data by comparing the recruitment strategies, the representative of the sample, the diagnosis of both “diabetes" and “depression”, and stratification by gender.

\subsection{Statistical Analysis}

The incidence rate of depression cases among the Arab female T2DM clients was treated as discrete variables. The prevalence rate and accompanying 95\% confidence intervals were pooled using random-effects model in Comprehensive meta-analysis (CMA) versions 3. The number of depression cases was extracted from the cross sectional studies included in this review (Table 1). Furthermore, Statistical heterogeneity was assessed in this review using I2 statistic.

\section{Results}

Overall, 40 articles were identified for potential inclusion in the review using EBSCO Academic Complete. A secondary study with the same search words was then completed using Web of Science. That search yielded 13 studies. None of those studies were unique. Therefore, the original 40 articles were screened for inclusion (Figure 1).

The data extractors rejected 36 records for the following reasons: the article did not include T2DM, the participants were not adults, the participants were not Arab, the articles were not original research (but were review articles). Data extraction sheets were filled out on 9 studies [16] [17] [21]-[27].

After filling the data extraction sheets, the researcher extracted 9 studies, which were identical (Table 2).

Of the nine (9) studies, four (4) studies measured depression on diabetics using the Beck Depression Inventory, two (2) studies used the HADS, one (1) used the K6 depression and anxiety screening tool, one (1) used a 30 question self-administered questionnaire called the geriatric depression scale, and one (1) used the Center for Epidemiologic Studies Depression Scale (CES-S). Five of the nine studies used A1C testing, two studies accepted a previous clinical diagnosis, and two studies used both clinical diagnosis and A1C. The mean ages of the studies varied. One study specifically recruited people over 60 [16]. Six studies recruited mainly people in middle age [17] [23]-[27]. The other two studies recruited younger people [21] [22].

On prevalence of depression comorbidity between genders, four studies used the Beck Inventory. This tool picks up the presence of depressive symptoms that are mild extreme. Of the two studies that looked at HADS, the percentage of participants with comorbid diabetes and depression symptoms were fewer (23.4\% and 19.3\%). One study used Center for Epidemiologic Studies Depression Scale (CES-S) with 58.2\%. In all studies that compared men with women, there was a significant difference between the two, with diabetic women having significantly higher rates of depression. More studies should be carried out in this area to confirm these findings.

\section{Quantitative Data Synthesis}

Upon statistical analysis, all the studies (9) included in this review that assessed the prevalence of depression among T2DM clients in Arabic countries were combined in the random-effect model using Comprehensive Meta-analysis Version 3. Statistical heterogeneity result using I2 statistic was more than 75\%. Therefore, random effect model was used to estimate the prevalence of depression among T2DM clients. 
Table 1. Summary of the included study.

\begin{tabular}{|c|c|c|c|c|c|}
\hline $\begin{array}{l}\text { Author, year, } \\
\text { country }\end{array}$ & $\begin{array}{c}\text { \#Total; } \\
\text { \#Female (\%) }\end{array}$ & Participant age & Number of depression (\%) & Diabetes assessment & $\begin{array}{l}\text { Depression } \\
\text { assessment }\end{array}$ \\
\hline $\begin{array}{l}\text { Bener et al., } \\
\text { 2012, Qatar }\end{array}$ & $\begin{array}{c}1660 ; 893 \\
\text { female }(53.8 \%)\end{array}$ & $\begin{array}{c}\text { Females mean } \\
\text { age was } 35.8\end{array}$ & $\begin{array}{l}23.4 \% \text { of women with } \\
\text { depressive symptoms had DM }\end{array}$ & $\begin{array}{l}\text { Self-reported DM type } \\
\text { 2, a file the clinic, and } \\
\text { HbA1c at the clinic }\end{array}$ & $\begin{array}{c}\text { Hospital Anxiety and Depression } \\
\text { Scale (HADS), HADS-A measured } \\
\text { anxiety and HADS-D measured } \\
\text { depression. }\end{array}$ \\
\hline $\begin{array}{l}\text { Hawamdeh et } \\
\text { al., 2013, UAE }\end{array}$ & $\begin{array}{c}\text { 182; } 182 \text { female } \\
(100 \%)\end{array}$ & $\begin{array}{c}71.5 \% \text { were } \\
18 \text { - } 39\end{array}$ & $\begin{array}{c}64 \text { (76.9\%) of women who had } \\
\text { DM had mild, borderline or } \\
\text { moderate, severe or extreme } \\
\text { depression }\end{array}$ & AbA1c & $\begin{array}{l}\text { Beck Depression Inventory II } \\
\text { (BDI-II) }\end{array}$ \\
\hline $\begin{array}{l}\text { Al Hayek et al., } \\
\text { 2013, KSA }\end{array}$ & $\begin{array}{c}\text { 101; } 33 \text { female } \\
\text { (33\%) }\end{array}$ & $\begin{array}{l}\text { Mean age was } \\
57.3\end{array}$ & $\begin{array}{c}\text { Baseline depression in the total } \\
\text { population of patients with DM: } \\
19.3 \%\end{array}$ & $\begin{array}{l}\text { Previous clinical diag- } \\
\text { nosis }\end{array}$ & $\begin{array}{c}\text { Arabic measure of the K6 } \\
\text { depression and anxiety screening } \\
\text { tool }\end{array}$ \\
\hline $\begin{array}{l}\text { Sulaiman et al., } \\
\text { 2010, UAE }\end{array}$ & $\begin{array}{l}\text { 347; } 227 \text { female } \\
\text { (65.4\%) }\end{array}$ & $\begin{array}{l}\text { Mean age was } \\
53.2\end{array}$ & $\begin{array}{l}12.5 \% \text { of patients obtained a } \\
\text { score of } 19 \text { or above on the K6 }\end{array}$ & $\begin{array}{l}\text { previous diagnosis, chart } \\
\text { review, FBS and AC1 }\end{array}$ & $\begin{array}{c}\text { Arabic measure of the K6 } \\
\text { depression and anxiety screening } \\
\text { tool }\end{array}$ \\
\hline $\begin{array}{l}\text { Sweileh et al., } \\
2014 \text { Palestine }\end{array}$ & $\begin{array}{c}246 ; 164 \text { female } \\
(67 \%)\end{array}$ & $\begin{array}{l}\text { Median age was } \\
60\end{array}$ & $\begin{array}{c}164 \text { women, } 77 \text { (47\%) had a } \\
\text { BDI-II }\end{array}$ & $\begin{array}{l}\text { self-reported } \\
\text { diabetes type 2, clinic } \\
\text { file, and HbA1c }\end{array}$ & $\begin{array}{l}\text { Beck Depressions Inventory } \\
\text { (BDI-II) }\end{array}$ \\
\hline $\begin{array}{l}\text { Al-Amer et al., } \\
\text { 2011, Jordan }\end{array}$ & $\begin{array}{c}\text { 649; 581, } \\
\text { T2DM } \\
(89.5 \%) 367 \\
\text { female }(56.5 \%)\end{array}$ & $\begin{array}{l}\text { Mean age was } \\
57.3\end{array}$ & $\begin{array}{c}\text { 20.1\% of T2DM patients and } \\
23.4 \% \text { female diabetic obtained } \\
\text { a score of } 10 \text { or above on the } \\
\text { PHQ-8 }\end{array}$ & $\begin{array}{l}\text { previous diagnosis, chart } \\
\text { review, and HbA1c }\end{array}$ & $\begin{array}{l}\text { Patients’ Health Questionnaire-8 } \\
\text { (PHQ-8) }\end{array}$ \\
\hline $\begin{array}{l}\text { Bensbaa et al., } \\
2014\end{array}$ & $\begin{array}{l}\mathrm{N}=14265.5 \% \\
\text { were women }\end{array}$ & $\begin{array}{l}\text { Average age was } \\
56.26 \pm 9 \text { years }\end{array}$ & $\begin{array}{c}93 \text { women }(\mathrm{T} 2 \mathrm{DM}) \\
\text { Prevalence of depression is } \\
33.1 \mathrm{n}=31\end{array}$ & Clinical records & $\begin{array}{c}\text { The Moroccan-Arabic version of } \\
\text { the Beck diagnostic scale of } \\
\text { depression }\end{array}$ \\
\hline $\begin{array}{l}\text { ElMahalli, } \\
\text { 2015, KSA }\end{array}$ & $\begin{array}{c}\mathrm{N}=269 \text { Female } \\
54.2 \%\end{array}$ & $\begin{array}{l}\text { Average age } \\
53.19 \pm 10.7\end{array}$ & $58.2 \% 82$ women out of 141 & $\begin{array}{l}\text { Previous diagnosis, } \\
\text { chart review, and } \\
\text { HbA1c }\end{array}$ & $\begin{array}{l}\text { The Center for Epidemiologic } \\
\text { Studies Depression Scale (CES-S) }\end{array}$ \\
\hline $\begin{array}{l}\text { Gemeay, 2015, } \\
\text { KSA }\end{array}$ & $\begin{array}{l}\mathrm{N}=100(62.1 \% \\
\text { is the female } \\
\text { percentage who } \\
\text { have T2DM) }\end{array}$ & $\begin{array}{l}\text { Average age was } \\
58.6\end{array}$ & $66 \%(22)$ & $\begin{array}{l}\text { Previous diagnosis, } \\
\text { chart review, and } \\
\text { HbA1c }\end{array}$ & $\begin{array}{l}\text { Beck Depression Inventory (BDI) } \\
\text { A 21-item screening questionnaire } \\
\text { comprising } 13 \text { cognitive, and } 8 \\
\text { somatic questions used to screen for } \\
\text { depression }\end{array}$ \\
\hline
\end{tabular}

Table 2. Summary of the included study: events and sample size.

\begin{tabular}{|c|c|c|c|}
\hline$\#$ & Author, year, country & \# Of event & Sample size \\
\hline 1 & Bener et al., 2012, Qatar & 76 & 431 \\
\hline 2 & Hawamdeh et al., 2013, UAE & 45 & 70 \\
\hline 3 & Al Hayek et al., 2013, KSA & 3 & 33 \\
\hline 4 & Sulaiman et al., 2010, UAE & 28 & 227 \\
\hline 5 & Sweileh et al., 2014 Palestine & 77 & 164 \\
\hline 6 & Al-Amer et al., 2011, Jordan & 86 & 367 \\
\hline 7 & Bensbaa et al., 2014 (Moroco) & 31 & 93 \\
\hline 8 & ElMahalli, 2015, KSA & 82 & 141 \\
\hline 9 & Gemeay, 2015, KSA & 29 & 44 \\
\hline
\end{tabular}

Figure 2 exhibits the pooled estimate of depression among T2DM clients in Arabic from nine studies. The outcome was the proportion of diabetic client who showed symptoms of depression based on Beck Depression Inventory II (BDI-II), Arabic measure on the K6 depression and anxiety; and patient's Health Questionnaire-8 (PHQ-8) and The Center for Epidemiologic Studies Depression Scale (CES-S). The effect size is the prevalence 


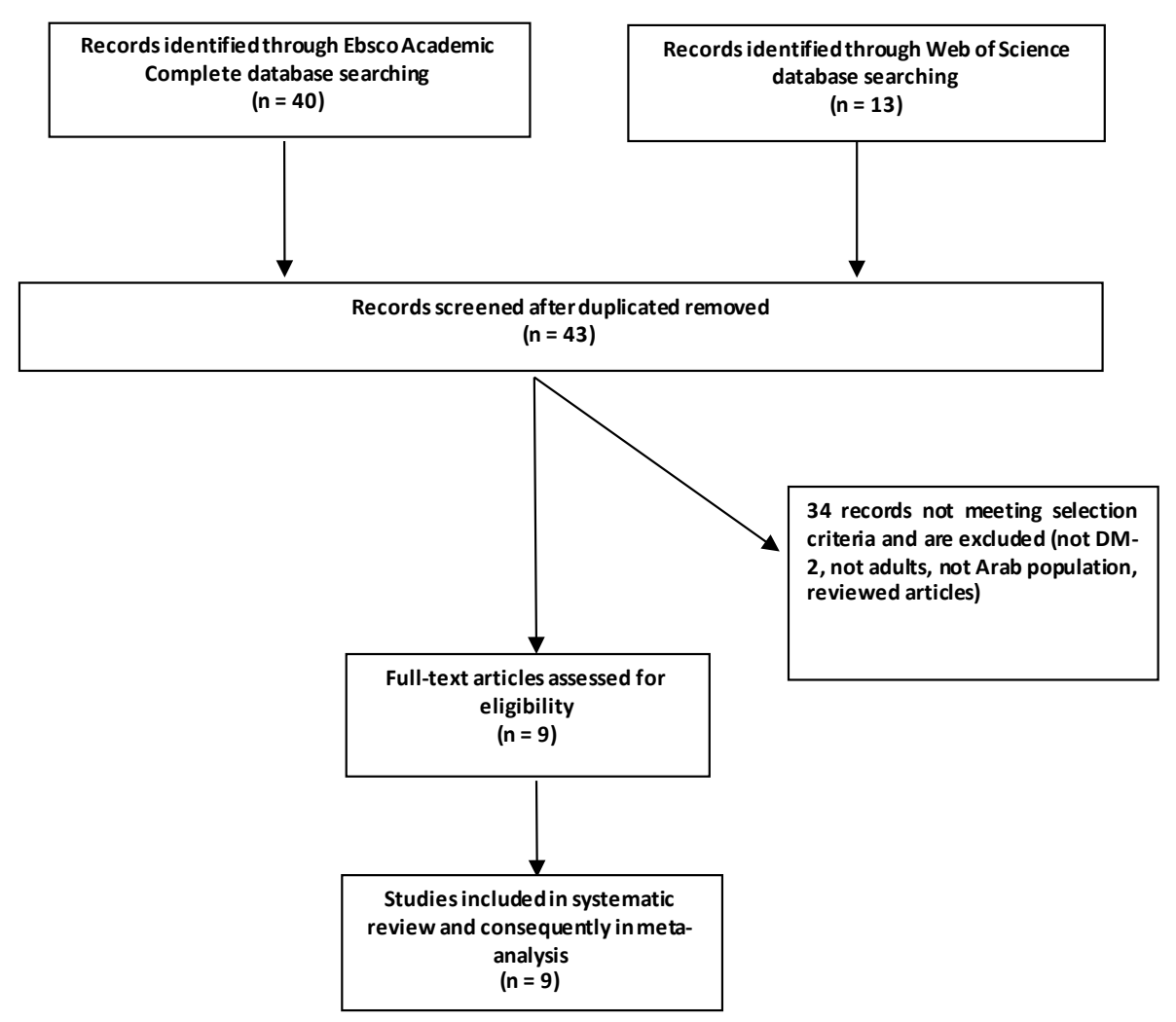

Figure 1. Flow diagram for selection of studies.

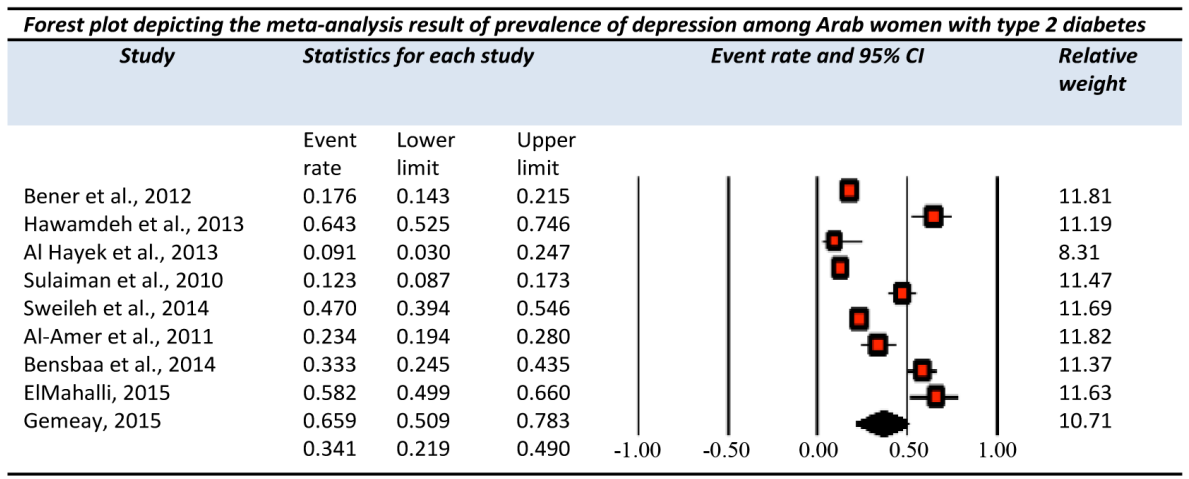

Figure 2. Pooled estimate of depression among T2DM Arab women.

of depression. The mean prevalence is 0.341 with a $95 \%$ confidence interval of 0.219 to 0.490 , which means that about $34.1 \%$ of the Arabic T2DM clients have varying degree of depression.

\section{Discussion}

The prevalence rate of depression among Arab women with T2DM is significant at $34.1 \%$ within $95 \%$ confidence level. This means that the Arab women with T2DM are not isolated from the prevalence of depression among individuals with DM throughout the world. Women comprise half of the population in the Arab countries. The fact that women are potential source of human force in the nation's economy, beside the huge domestic role in keeping their homes and families, merit more attention to direct attention on their health and well-being.

While these studies used different measures to assess risk for depression and anxiety, it is clear that there is evidence of high rates of both mental stress and T2DM in women in this region [28]. This finding is consistent with what the researchers have been seeing in several Arabic countries. While no longitudinal studies were iden- 
tified in women in Arab countries measuring the relationship between diabetes and depression, the relationship has been established elsewhere. A meta-analysis, which looked globally at the relationship, identified 16 studies, which were longitudinal [29]. This article reported a positive association between diabetes and depression. Furthermore, this co-morbidity also results in a 1.5 fold increase in mortality from all causes.

Regional and intra-country data on diabetes should be increased. It is interesting to look at the EMRO region compared to the African region to the south. In Africa, rates of diabetes are much lower than EMRO and gender does not appear to be as predictive a factor for T2DM diagnosis. One meta-analysis looking at gender differences in Sub-Saharan Africa for prevalence of T2DM found that 5.7\% of people overall are diabetic, with men having lower rates than women (5.5\%; compared with 5.9\%) [30]. Studies should be done to compare regional findings.

Women have higher risk of depression than men. One study from the US measured depression in over 2200 people, and found that the prevalence of major depression was 3.8\% overall, with $4.4 \%$ of women and 3.3\% depression in men [22]. In Arab countries, there has also been evidence of this trend [31]. The reasons for this difference are yet unknown.

One potential contributing factor to women in Arab countries having the comorbidity of depression and T2DM is Vitamin D deficiency. A relationship between Vitamin D deficiency and depression has been found [32]. This study found that there were lower serum Vitamin D levels in participants with psychological problems than those without $(\mathrm{p}<0.05)$.

One of the reasons why there were limited studies on this subject, may be because of cultural issues, which makes screening for both T2DM and depression more difficult. It is likely that in Arab countries, both T2DM and depression are heavily under-reported.

\section{Conclusions}

Significant rate of the prevalence of depression among Arab women with T2DM in the Arab countries cannot be discounted. Despite limited studies on Arab women in the Arab countries on depression and T2DM, findings of this review and analysis revealed a considerable phenomenon that is possibly increasing when properly assessed, documented, and given attention. Depression as a comorbidity of T2DM is as debilitating as T2DM itself, but being understudied, depression in T2DM is neglected and unattended among individuals with T2DM.

Depression has recently become a focus of global concern. Tackling depression requires great determination as there are many factors that would hinder its positive advancement such as the stereotype of shame that accompanies such a disorder. Furthermore there are often limited mental healthcare resources especially in low to moderate-income countries.

Women experiencing depression in such countries face a great amount of struggle as there is merely no access to any mental healthcare facilities or even specialists and even if available, their modest income would not allow such a visit. Likewise, these countries are only providing weak health systems that are incapable of handling chronic conditions such as T2DM and depression as not too long ago they were preoccupied in dealing with infectious diseases in their communities.

More studies need to be done in order to verify a causal relationship between depression and diabetes. Multisite studies should be done with consistent methodology. Long-term cohort studies should be done to lend evidence to causation (do T2DM Arab women develop depression or do depressed women develop T2DM).

In order for these studies to take place, screening needs to be done in a culturally sensitive way. Social marketing should be done to promote acceptance of people with dual diagnosis of T2DM and depression. Treatment options should be assessed, developed and offered to women throughout the Arab region.

\section{References}

[1] Andreoulakis, E.H., Kandylis, T. and Iacovides, A. (2012) Depression in Diabetes Mellitus: A Comprehensive Review. Hippokratia, 16, 205-214.

[2] Hill, S.G., Lazo, M., Carnethon, M., Bertoni, A.G., Schreiner, P.J., Diez Roux, A.V., Benjamin Lee, H. and Lyketsos, C. (2008) Examining a Bidirectional Association between Depressive Symptoms and Diabetes. JAMA, 299, 27512759. http://dx.doi.org/10.1001/jama.299.23.2751

[3] Anderson, R.J., Freedl, K.E., Clouse, R.E. and Lustman, P.J. (2001) The Prevalence of Comorbid Depression in Adults with Diabetes: A Meta-Analysis. Diabetes Care, 24, 1069-1078. http://dx.doi.org/10.2337/diacare.24.6.1069 
[4] Talbot, F. and Nouwen, A. (2000) A Review of the Relationship between Depression and Diabetes in Adults: Is There a Link? Diabetes Care, 23, 1556-1562. http://dx.doi.org/10.2337/diacare.23.10.1556

[5] Mezuk, B., Eaton, W.W., Albrecht, S. and Golden, S.H. (2008) Depression and Type 2 Diabetes over the Lifespan: A Meta-Analysis. Diabetes Care, 31, 2383-2390. http://dx.doi.org/10.2337/dc08-0985

[6] WHO (2006) Diabetes in the Eastern Mediterranean Region. http://applications.emro.who.int/dsaf/dsa664.pdf

[7] Wild, S., Roglic, G., Green, A., Sicree, R. and King, H. (2004) Global Prevalence of Diabetes: Estimates for the Year 2000 and Projections for 2030. Diabetes Care, 27, 1047-1053. http://dx.doi.org/10.2337/diacare.27.5.1047

[8] (2011) International Diabetes Federation, IDF Diabetes Atlas, International Diabetes Federation, Brussels, Belgium, 5th Edition. http://www.idf.org/diabetesatlas

[9] Badran, M. and Laher, I. (2012) Type II Diabetes Mellitus in Arabic-Speaking Countries. International Journal of Endocrinology, 2012, Article ID: 902873. http://dx.doi.org/10.1155/2012/902873

[10] WHO (2012) World Health Statistics 2012. www.who.int/gho/publications/world_health_statistics/2012/en/

[11] WHO. Revised Global Burden of Disease (GBD) 2002 Estimates. www.who.int/healthinfo/global_burden_disease/...2002_revised/en/

[12] Moussavi, S., Chatterji, S., Verdes, E., Tandon, A., Patel, V. and Ustun, B. (2007) Depression, Chronic Diseases, and Decrements in Health: Results from the World Health Surveys. Lancet, 370, 851-858. http://dx.doi.org/10.1016/S0140-6736(07)61415-9

[13] Alhyas, L., McKay, A., Balasanthiran, A. and Majeed, A. (2011) Prevalences of Overweight, Obesity, Hyperglycaemia, Hypertension and Dyslipidaemia in the Gulf: Systematic Review. JRSM Short Reports, 2, 55. http://dx.doi.org/10.1258/shorts.2011.011019

[14] Collins, M.M., Corcoran, P. and Perry, I.J. (2009) Anxiety and Depression Symptoms in Patients with Diabetes. Diabetic Medicine, 26, 153-161. http://dx.doi.org/10.1111/j.1464-5491.2008.02648.x

[15] Antonio, E., Pontiroli, M.D., Donatella, C. and Alberto, M. (2013) Female Sexual Dysfunction and Diabetes: A Systematic Review and Meta-Analysis. The Journal of Sexual Medicine, 10, 1044-1051. http://dx.doi.org/10.1111/jsm.12065

[16] Sweileh, W.M., Abu-Hadeed, H.M., Al-Jabi, S.W. and Zyoud, S.H. (2014) Prevalence of Depression among People with Type 2 Diabetes Mellitus: A Cross Sectional Study in Palestine. BMC Public Health, 14, 163. http://dx.doi.org/10.1186/1471-2458-14-163

[17] Al-Amer, R.M., Sobeh, M.M., Zayed, A.A. and Al-Domi, H.A. (2011) Depression among Adults with Diabetes in Jordan: Risk Factors and Relationship to Blood Sugar Control. Journal of Diabetes and Its Complications, 25, $247-252$. http://dx.doi.org/10.1016/j.jdiacomp.2011.03.001

[18] Asghar, S., Hussain, A., Ali, S.M., Khan, A.K. and Magnusson, A. (2007) Prevalence of Depression and Diabetes: A Population-Based Study from Rural Bangladesh. Diabetic Medicine, 24, 872-877. http://dx.doi.org/10.1111/j.1464-5491.2007.02136.x

[19] Offenhauer, P. (2005) Women in Islamic Societies: A Selected Review of Social Scientific Literature. https://www.loc.gov/rr/frd/pdf-files/Women_Islamic_Societies.pdf

[20] Cochrane (2013) Data Extraction Form. http://www.google.com.sa/url?sa=t\&rct=j\&q=\&esrc=s\&source=web\&cd=1\&ved=0CDAQFjAA\&url=http $\% 3 A \% 2 F \%$ 2Fhiv.cochrane.org

[21] Bener, A., Al-Hamaq, A.O.A.A. and Dafeeah, E.E. (2011) High Prevalence of Depression, Anxiety and Stress Symptoms among Diabetes Mellitus Patients. The Open Psychiatry Journal, 5, 5-12. http://dx.doi.org/10.2174/1874354401105010005

[22] Hawamdeh, S., Almakhzoomy, I. and Hayajneh, Y. (2013) Screening and Correlates of Depression and HbA $1 \mathrm{C}$ in United Arab Emirates (UAE) Women with Diabetes. Perspectives in Psychiatric Care, 49, 262-268.

[23] Al Hayek, A.A., Robert, A.A., Al Dawish, M.A., Zamzami, M.M., Sam, A.E. and Alzaid, A.A. (2013) Impact of an Education Program on Patient Anxiety, Depression, Glycemic Control, and Adherence to Self-Care and Medication in Type 2 Diabetes. Journal of Family and Community Medicine, 20, 77-82. http://dx.doi.org/10.4103/2230-8229.114766

[24] Sulaiman, N., Hamdan, A., Tamim, H., Mahmood, D.A. and Young, D. (2010) The Prevalence and Correlates of Depression and Anxiety in a Sample of Diabetic Patients in Sharjah, United Arab Emirates. BMC Family Practice, 11, 80. http://dx.doi.org/10.1186/1471-2296-11-80

[25] Bensbaa, S., Agerd, L., Boujraf, S., Araab, C., Aalouane, R., Rammouz, I. and Ajdi, F. (2014) Clinical Assessment of Depression and Type 2 Diabetes in Morocco: Economical and Social Components. Journal of Neurosciences in Rural Practice, 5, 250-253. http://dx.doi.org/10.4103/0976-3147.133576

[26] El Mahalli, A. (2015) Prevalence and Predictors of Depression among Type 2 Diabetes Mellitus Outpatients in Eastern 
Province, Saudi Arabia. International Journal of Health Sciences, 9, 119-126.

[27] Gemeay, E.M., Moawed, S.A., Mansour, E.A., Ebrahiem, N.E., Moussa, I.M. and Nadrah, W.O. (2015) The Association between Diabetes and Depression. Saudi Medical Journal, 36, 1210-1215. http://dx.doi.org/10.15537/smj.2015.10.11944

[28] Van Dooren, F.E., Nefs, G., Schram, M.T., Verhey, F.R., Denollet, J. and Pouwer, F. (2013) Depression and Risk of Mortality in People with Diabetes Mellitus: A Systematic Review and Meta-Analysis. PLoS ONE, 8, e57058. http://dx.doi.org/10.1371/journal.pone.0057058

[29] Hilawe, E.H., Yatsuya, H., Kawaguchi, L. and Aoyama, A. (2013) Differences by Sex in the Prevalence of Diabetes Mellitus, Impaired Fasting Glycaemia and Impaired Glucose Tolerance in Sub-Saharan Africa: A Systematic Review and Meta-Analysis. Bulletin of the World Health Organization, 91, 671-682D. http://dx.doi.org/10.2471/BLT.12.113415

[30] Shen, Q. and Bergquist-Beringer, S. (2013) Relationship between Major Depression and Insulin Resistance: Does It Vary by Gender or Race/Ethnicity among Young Adults Aged 20 - 39 Years? Journal of Diabetes, 5, 471-481. http://dx.doi.org/10.1111/1753-0407.12044

[31] Chung, H.-K., Cho, Y., Choi, S. and Shin, M.J. (2014) The Association between Serum 25-Hydroxyvitamin D Concentrations and Depressive Symptoms in Korean Adults: Findings from the Fifth Korea National Health and Nutrition Examination Survey 2010. PLoS ONE, 9, e99185. http://dx.doi.org/10.1371/journal.pone.0099185

[32] Ravona-Springer, R. and Schnaider Beeri, M. (2014) A Spectrum of Contributions of Type 2 Diabetes and Related Metabolic Characteristics to Dementia. European Neourpsychopharmacology, 24, 1945-1946. http://dx.doi.org/10.1016/j.euroneuro.2014.11.009 